\title{
Transformer species in the flora of the Starobilsk grass-meadow steppe (Ukraine)
}

\author{
Oksana O. Kucher
}

Taras Shevchenko Luhansk National University, Department of Biology, Oboronna 2, 91011 Luhansk, Ukraine; M. G. Kholodny Institute of Botany, National Academy of Sciences of Ukraine, Tereschenkivska 2, 01601 Kiev, Ukraine, e-mail: prykhodko.oksana@mail.ru

\begin{abstract}
The results of an investigation of alien species that change the character, condition, form or nature of ecosystems over large areas (transformer species) in the flora of the Starobilsk grass-meadow steppe are presented. The check-list of alien plants includes over 386 species of vascular plants, of which 28 are invasive and 6 are transformer species. In this study, the data on the first records of alien species, their distribution history, ecology, occurrence in different plant communities and degree of naturalization were compiled. The distribution maps of transformer species are provided.
\end{abstract}

Key words: alien plant species, transformer species, plant invasions, Ukraine

\section{Introduction}

Since the end of the 20th century, the process of flora synanthropisation has been increasing all over the world and in Ukraine particularly. The problem is especially important in the east of Ukraine (Protopopova et al. 2002). This may result from the following facts: firstly, the natural vegetation of Starobilsk grass-meadow steppe area is highly fragmented, which facilitates naturalization of alien species in semi-natural and natural ecosystems, and, secondly, because of intense human activity in this area (Protopopova 1991).

Invasive species constitute $8 \%$ of alien fraction of Ukrainian flora and $10 \%$ of invasive species belong to 'transformers'. Alien species can not only migrate to new locations, but also change the character, condition, form or nature of ecosystems over large areas (Richardson et al. 2000). These species are charcterised by a rapid rate of spread and a high degree of naturalization, including coenotic activity, stress-tolerance and broad ecological amplitude. Transformers comprise species that are excessive users of natural resources (e.g., water and light), donors of limited resources (e.g. nitrogen), stabilize sandy soil;, colonize intertidal mudflats; accumulate, litter and pollutants; accumulate and redistribute salt and affect fires (Richardson et al. 2000; Vinogradova et al. 2009).
Three periods of studies of the adventive fraction of Starobilsk grass-meadow steppe can be distinguished (Kucher 2011). The first data on the alien species occurrence in this area were reported in the books of Chernyaev (1859) and Schmalhausen (1895), which describe some species of alien origin. More detailed investigations of this region's flora, including lists of plants, were initiated in the early $20^{\text {th }}$ century. The most important scientific papers of this period were published by Taliyev (1907), Hrossheym and Akynfyev (1907), Uhrynsky and Shiryaev (1903) and Kotov (1949). After 1930, researchers paid particular attention to the comprehensive studies of weeds (Kucher 2011). The special investigations of adventive fraction of flora in this region were related to the work of Protopopova (1973). The research of the flora of this region was carried out by the group of scientists (E. M. Kondratyuk, D. S. Ivashin, R. I. Burda, G. I. Kharhota). It resulted in the publication of Checklist of flora of South-East of Ukraine (Kondratyuk et al. 1985). Various routes of communications (roads and railways) are the most studied areas of alien fraction occurrence in this region (Burda 1997; Tokhtar 2005; Konoplja \& Drel 1998).

In general, investigations conducted so far show that there is a tendency for a continuous increase in the number of alien species in the flora of the region and increase in the degree of naturalization of some species. 
Checklist of flora of South-East of Ukraine (Kondraytuk et al. 1985) includes 101 alien species. This fraction of flora has increased to 431 species during 25 years (Ostapko et al. 2010).

The main objectives of research was (i) to identify invasive and transformer species in the study area (ii) to study the character of their spread in the region, and (iii) the impact of their occurrence on plant communities.

\section{Material and methods}

The present research focuses on the transformer species of Starobilsk grass-meadow steppe. Investigations are based on original data obtained by routine surveys in 2008-2013, analysis of data in the literature and examination of collections of the Herbaria of M. G. Kholodny Institute of Botany, National Academy of Sciences of Ukraine (KW), Donetsk Botanical Garden, NAS of Ukraine (DNZ) and Taras Shevchenko Luhansk National University.

Comparative morphological and geographical methods were used in the present investigations. The classification of alien plant species followed Kornaś (1968), modified by Protopopova (1991). Invasive and transformer groups were determined according to Richardson et al. (2000). Invasive alien species are naturalized species that produce reproductive offspring, often in very large numbers, at considerable distances from parent plants and, thus, have the potential to spread over a considerable area. Transformer species are a subset of invasive species. They change the character, condition, form or nature of ecosystems over a substantial area, depending on the extent of a given ecosystem. Life forms (acc. to Raunkiaer 1934) and morphological types of plants with respect to soil moisture (acc. to Didukh 2000) in the transformer group of were analysed. Characteristics of species distribution area was prepared according to the Flora of European part of USSR (Fedorov 1974-1987; Tzvelev 1989-1994) and Flora of Eastern Europe (Tzvelev 1996-2004). The species names were given according to Mosyakin $\&$ Fedoronchuk (1999). Data on the first record of the studied species, history of spread ecology, occurrence in the different plant communities and degree of naturalization were compiled (Protopopova 1991). The above groups are segregated according to the traditional classification (see Kornaś 1968), modified by Protopopova (1991) (Table 1).

The dot map of distribution of transformer species in the studied region was prepared based on the herbarium and field data. The squares of UTM system $(100 \times 100 \mathrm{~km})$ were divided into smaller units of $50 \times 50 \mathrm{~km}$ and $10 \times 10 \mathrm{~km}$ (Budzhak et al. 2009; Kucher \& Guz' 2014).

\section{Study area}

The Starobilsk grass-meadow steppe is located in the east of Ukraine (easternmost part of Luhansk province and some districts of Donetsk and Kharkiv regions). It was subject to intensive anthropogenic changes and transformation of plant cover. The regional ecosystems are a heterogenic complex, which

Table 1. Classification criteria and categories of alien species

\begin{tabular}{|c|c|}
\hline Name of the group & Characteristics of alien species \\
\hline \multicolumn{2}{|r|}{ Classification criterion: degree of naturalization } \\
\hline Agriophytes & Plants naturalized in natural and seminatural habitats \\
\hline Hemiagriophytes & Plants naturalized mostly in seminatural or disturbed habitats \\
\hline Epoecophytes & Plants naturalized in man-made and disturbed habitats \\
\hline Colonophytes & $\begin{array}{l}\text { Plants that occur in the area in one to several stable colonies } \\
\text { but which show little or no trend toward further expansion }\end{array}$ \\
\hline Ephemerophytes & Non-naturalized alien species, occasional migrants, or waifs \\
\hline \multicolumn{2}{|r|}{ Classification criterion: time of migration } \\
\hline Archaeophytes & Plants that migrated before the end of the 15 th century. \\
\hline Kenophytes & $\begin{array}{l}\text { Plants that migrated between the } 16 \text { th century and the end of } \\
\text { the } 19 \text { th century }\end{array}$ \\
\hline Eukenophytes & Plants that migrated in the 20th century \\
\hline \multicolumn{2}{|r|}{ Classification criterion: way of distribution } \\
\hline Ergasiophytes & $\begin{array}{l}\text { Plants that were intentionally introduced and cultivated by } \\
\text { man, and then spread from places of their cultivation }\end{array}$ \\
\hline Xenophytes & Plants introduced unintentionally \\
\hline Xeno-ergasiophytes & $\begin{array}{l}\text { Plants cultivated outside of the studied area but unintentionally } \\
\text { introduced to the Starobilsk grass-meadow steppe }\end{array}$ \\
\hline
\end{tabular}




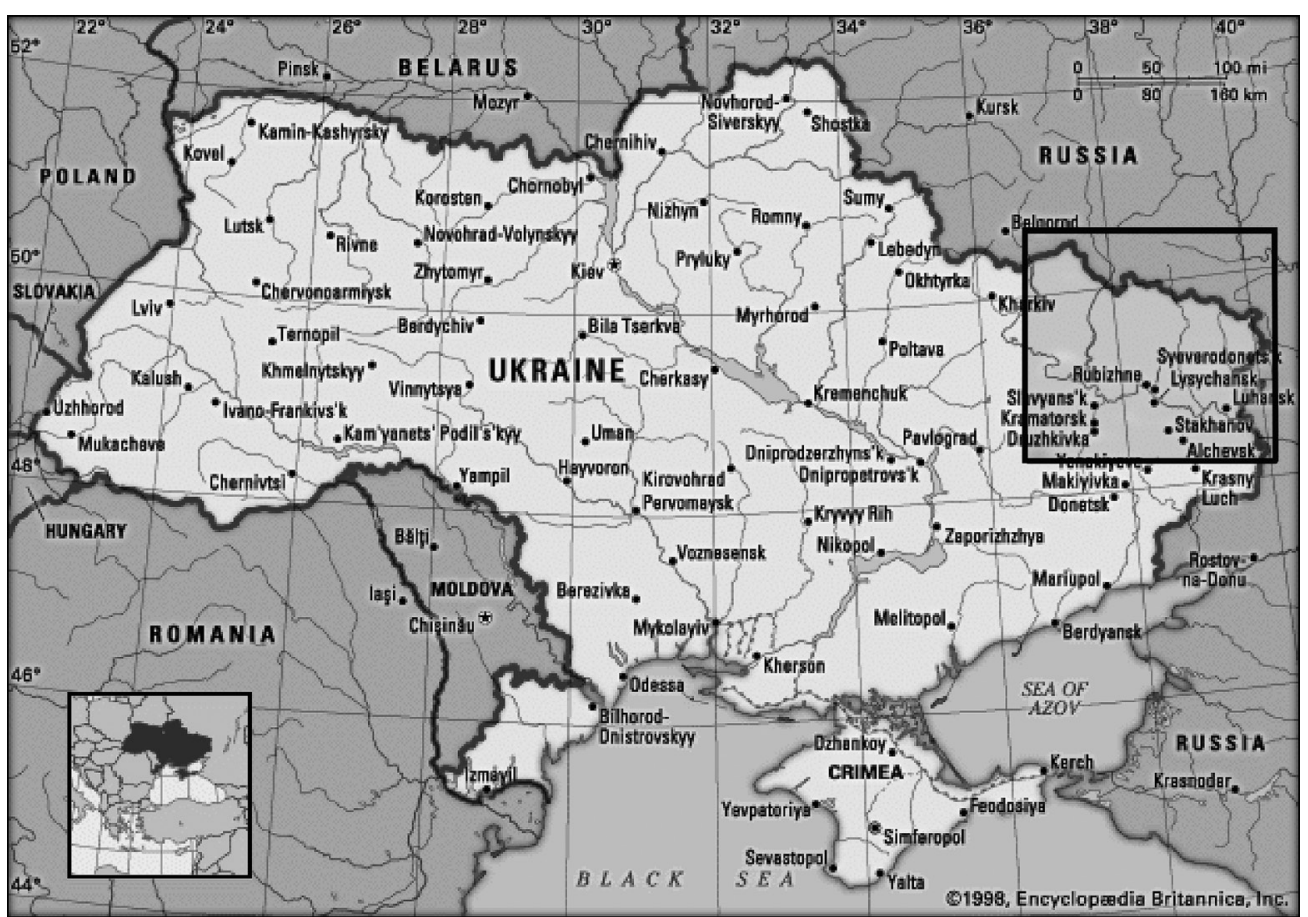

Fig. 1. The locality of the Starobilsk grass-meadow steppe

includes ravine and artificial forest, meadow-steppe, steppe, riverine natural vegetation, human-made and human-altered habitats. According to the physical and geographical zoning of Ukraine (Marynych et. al. 2003), the studied area belongs to the northern subzone, steppe zone, East European Plain. It covers nearly $1900 \mathrm{~km}^{2}$.

The Starobilsk grass-meadow steppe has clearly defined boundaries: in the North and in the East - the state border with Russian Federation (Rostov and Belgorod region), in the West - the river Oskol (left bank), in the South - the Seversky Donets river (left bank) (Fig. 1). Besides the Seversky Donets, the main rivers are Aydar, Derkul, Krasna, Evsug and Oskol.

The climate of Starobilsk grass-meadow steppe is the most continental in comparison with other steppe regions of Ukraine. Fertile soils are mainly black soils in the floodplain of Seversky Donets. Large cities of the region include Starobilsk, Svatove, Novoaydar, Sevevodonetsk and Kupyansk.

\section{Results}

Our preliminary check-list of alien fraction of Starobilsk grass-meadow steppe flora includes over 386 species of vascular plants from 229 genera and 64 families. Most of them are kenophytes (262 species), the rest are archaeophytes (104), according to the time of migration.

We noted 28 invasive species: Acer negundo L., Ailanthus altissima (Mill.) Swingle, Amaranthus blitoides S. Watson, Amaranthus retroflexus L., Ambrosia artemisiifolia L., Amorpha fruticosa L., Bidens frondosa L., Bromus squarrosus L., Capsella bursa-pastoris (L.) Medic., Cardaria draba (L.) Desv., Centaurea diffusa Lam., Cichorium intybus L., Conium maculatum L., Conyza canadensis L., Cyclachaena xanthiifolia (Nutt.) Fresen., Diplotaxis tenuifolia (L.) DC., Echinochloa crussgalli (L.) P. Beauv., Elaeagnus angustifolia L., Galinsoga parviflora Cav., Grindelia squarrosa (Pursh) Dunal, Helianthus tuberosus L., Portulaca oleracea L., Robinia pseudoacacia L., Setaria glauca L., Sonchus oleraceus L., Ulmus pumila L., Vicia villosa Roth and Xanthium albinum (Widder.) H. Scholz. They have naturalized and actively spread through the region.

The leading families of invasive species are: Asteraceae (11 species), Fabaceae, Brassicaceae and Poaceae ( 3 each) and Amaranthaceae (2). The invasive species of adventive fraction of flora of the Starobilsk grassmeadow steppe vary in origin. Most of them originate from the North America (13 species), the Mediterranean (8) and Asia (6). With respect to the time of migration, most of them are kenophytes (20 species), while archaeophytes include only 8 species. In terms of introduction method, xenophytes dominate, while ergasiophytes comprise only 7 species. According to the degree of naturalization - epoecophytes and agriophytes prevail in this group. With regard to life forms, the largest group consists of annuals (14 species), followed by biennials and perennial (8) and shrubs and trees (7). 
We identified 6 transformer species of invasive plants: Acer negundo, Amaranthus retroflexus, Ambrosia artemisiifolia, Amorpha fruticosa, Grindelia squarrosa and Ulmus pumila. Below, there is a brief description of transformer species based on the previously adopted scheme (Protopopova et. al. 2009, 2010, 2012).

Acer negundo L. (kenophytes, agriophytes, ergasiophytes, phanerophytes, xeromesophytes to the hydromorphes, scyheliophytes to the heliomorphes - Protopopova \& Shevera 2014; Vinogradova et al. 2009). A. negundo is a species of the North American origin. In the natural conditions, it occurs in the marsh forests of the USA and Canada (Tzvelov 1996-2004). This species was deliberately introduced in 1688 in Europe; in Russia, A. negundo is cultivated in the Imperial Botanical Garden since 1796 year. In Ukraine, this species was brought to Kharkov in 1809 and, then, to the eastern part of Ukraine (Velyko-Anadolskyi forestr district, modern Donetsk Reg.) in 1865 (Protopopova et al. 2010; Protopopova \& Shevera 2014). In the $20^{\text {th }}$ century, $A$. negundo was used to create shelter belts throughout the Starobilsk grassesmeadow steppe.

A. negundo has low demands regarding soil conditions, but it best grows on fertile, fresh soils, in well-lit areas. The species is fast growing and resistant to air pollution.
It is most aggressive in the early stages of invasion, due to rapid seed germination. At first, $A$. negundo spreads by self-seeding in the outskirts of cities and towns in disturbed habitats, but, later, it quickly migrates along communication routes (Protopopova et al. 2010; Protopopova \& Shevera 2014).

This species was monodominant in the floodplain, in many places of Seversky Donets River and its tributaries (Fig. 2). A. negundo inhibits the growth of seedlings, due to its biological properties. The species is distributed mainly along the road and railways and in shelter belts previously created to improve micro-climatic conditions. In such areas, $A$. negundo is often cultivated with another North American species - Robinia pseudoacacia, which actively spread over the territory of Starobilsk grassesmeadow steppe. A. negundo often grows with another transformer - Amorpha fruticosa, in the sandy areas of Aydar river floodplain. The alien species, Ambrosia artemisifilia and Xanthium albinum grow in the herb layer, on poor soils and may cover up to $50 \%$ of the area. The species is common in all towns and in ruderal habitats, where due to its rapid growth, it inhibits the growth of other species. A. negundo occurs sporadically in the protected natural areas of the region - in two parts of the Luhansk Nature Reserve.

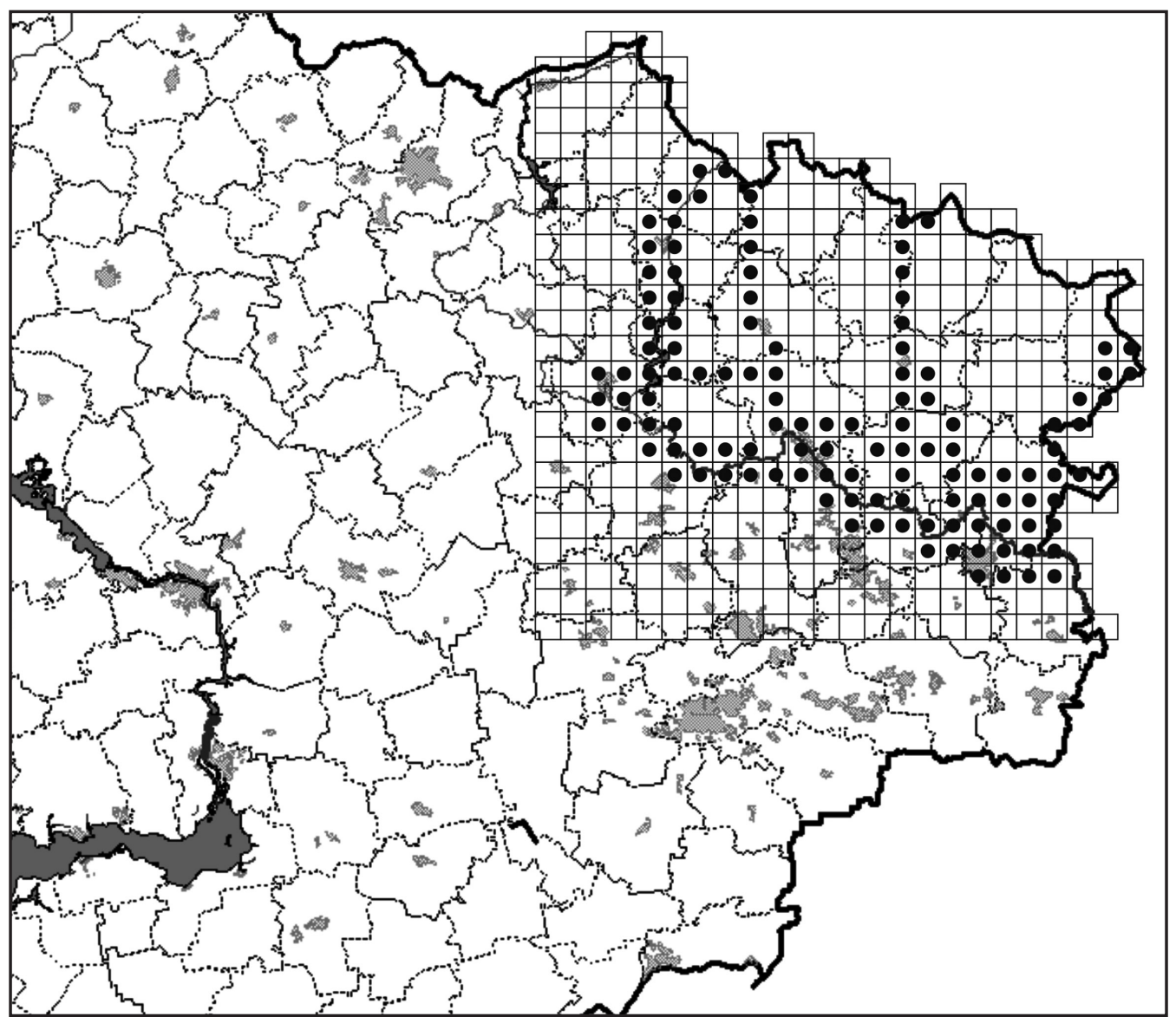

Fig. 2. Distribution map of Acer negundo L. in the Starobilsk grass-meadow steppe 
Ulmus pumila L. (kenophytes, epoecophytes, ergasiophytes, phanerophytes, xeromesophytes, heliophytes - Protopopova \& Shevera (2014). U. pumila is the species of Central Asian origin (Protopopova \& Shevera 2014), widely cultivated in Asia and North America, to a lesser extent in Southern Europe. U. pumila was introduced to Spain in the $16^{\text {th }}$ century and, later, to Italy. U. pumila naturally hybridized with $U$. minor in Southern Europe. This species was introduced to the USA from the Far East in the early $20^{\text {th }}$ century. Later, it aggressively spread over the North America - from central Mexico through the Eastern and Central United States to Ontario and Canada. U. pumila hybridized with $U$. rubra - a species native to the USA. U. pumila is also widely distributed in the South America, over the whole territory of Argentine Pampas. Lately, the species has spread to Japan (Vasiliev 1986).

In the postwar years, U. pumila was often used in landscaping, in the cities of Eastern Ukraine and in forest belts to secure the slopes of embankments, as a fast-growing species that is able to withstand dry soil and air pollution (Burda 1997).

The species is light demanding and grows fast in sufficient light conditions. It is very resistant to drought and humus content of the soil. U. pumila is widespread in urban areas and has been migrating along the roads of Starobilsk grass-meadow steppe (Fig. 3). It mainly occurs on disturbed soils, along the railway tracks and roads. U. pumila often forms dense thickets with other alien trees: Acer negundo and Elaeagnus angustifolia. The species invades mature forests and rarely artificial pine forests on sandy soils, often due to its high demands for light. It occurs also in pastures and fallow lands.

Grindelia squarrosa (Pursh) Dunal (kenophytes, epoecophytes, ksenophytes, hemyryptophytes, xeromesophytes, heliophytes - Protopopova et al. (2002). G. squarrosa is the species of North American origin, successfully naturalized in the steppe zone of Ukraine and spreading in the western and northern directions. The species was brought into the territory of Ukraine in 1949 (Protopopova et al. 2009). Locality in the Luhansk region, near the town Slovianoserbsk in the riverine floodplain of Seversky Donets River, is one of the primary distribution centers of G. squarrosa, which has been probably existing since the Second World War, but was first found in 1962 (Kucher 2012).

G. squarrosa was found in the city of Luhansk and at the side of the Luhansk-Alchevsk road, near the village of Jubilejne. It forms almost monodominant communities with a projective cover of $50-60 \%$. Rare specimens

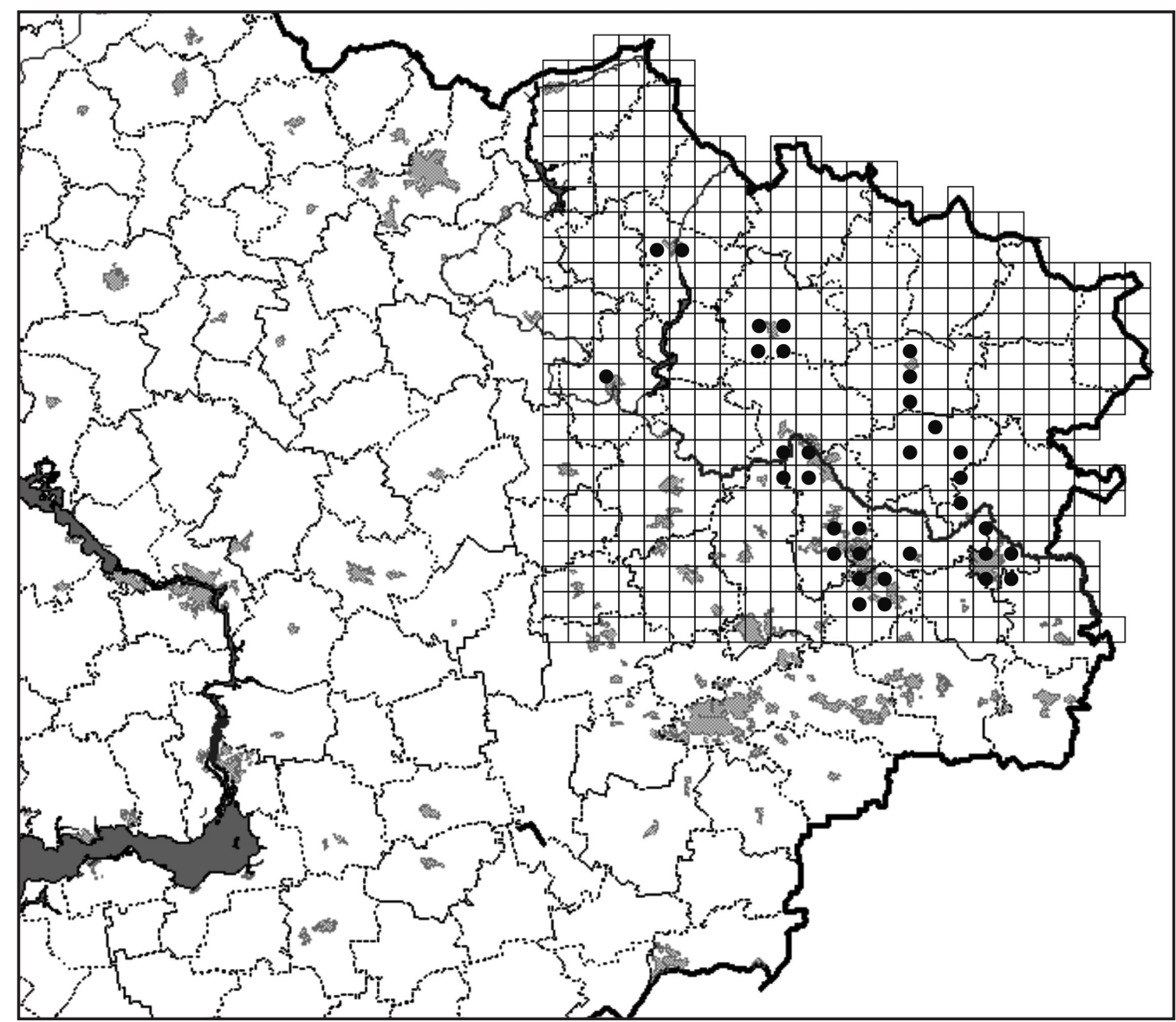

Fig. 3. Distribution map of Ulmus pumila L. in the Starobilsk grass-meadow steppe 
of G. squarrosa were noticed on a lawn in the center of Alchevsk city. The species has been spreading along railway tracks in the Luhansk region. Its localities were found around the following cities: Starobilsk, Novo Aydar, Stanychno-Lugansk, Svatove, Bilokurakyne, Lugansk (village Veselenke) and others (Fig. 4). It grows along roads in degraded sandy soils and often forms communities with the participation of Portulaca oleracea L. and Chenopodium sp. div.

G. squarrosa is distributed in the floodplain of Seversky Donets River and along its major tributaries of Derkul and Aydar, on sandy soils afforested with Pinus sylvestris L. in the postwar years. It forms communities with both native (Polygonum aviculare L., Elytrigia repens (L.) Nevski, Echium vulgare L., Medicago romanica Prod., Achilea submelifolium Klokov et Krytzka, Tanacetum vulgare L.) and adventive species (Portulaca oleracea, Cichorium intybus L., Ambrosia artemisiifolia L.). G. squarrosa spreads along the roadsides and railways tracks, inhabits heaps, flood plains, disturbed soils in large cities and in agricultural fields (especially rocky sites), coastal areas and rocky outcrops and talus slopes. It occurs in natural and synanthropic communities (on bulk substrates, ruderal rocky outcrops, talus slopes, fallows, in quarries, pastures and, ruderal shrubby areas).
Ambrosia artemisiifolia L. (kenophytes, epoecophytes, ksenophytes, terophytes, xeromesophytes, heliophytes Protopopova \& Shevera 2014). Ambrosia artemisiifolia is the species of North American origin. In Germany, it was introduced in 1863, with clover seeds. The species is now known on all continents (Protopopova et al. 2009). In Ukraine, it was cultivated as a medicinal plant since 1914 (Protopopova \& Shevera 2014). In the Luhansk region, A. artemisiifolia was found for the first time in 1927 at the Valuiki station, and, recently, the species has spread almost over the whole territory of the region (Konoplja \& Drel 1998)

The species takes up large amounts of moisture and nutrients from the soil, has allelopathic properties and, thus, dominates over and suppresses other plant growth (Konoplja \& Drel 1998; Protopopova \& Shevera 2014). Consistently, A. artemisiifolia occurs along the roads and railway tracks and in ruderal places of almost all towns of the Starobilsk grass-meadow steppe; often, along with other species of alien plants: Cyclachaena xanthiifolia and Conyza canadensis. Recently, the species was found in the floodplain of the Seversky Donets River and its tributaries (Aydar and Derkul), and on fallow agricultural land in ruderal bushy areas (Fig. 5). It is distributed on sandy soils, but we also found it on humus-rich soils. $A$.

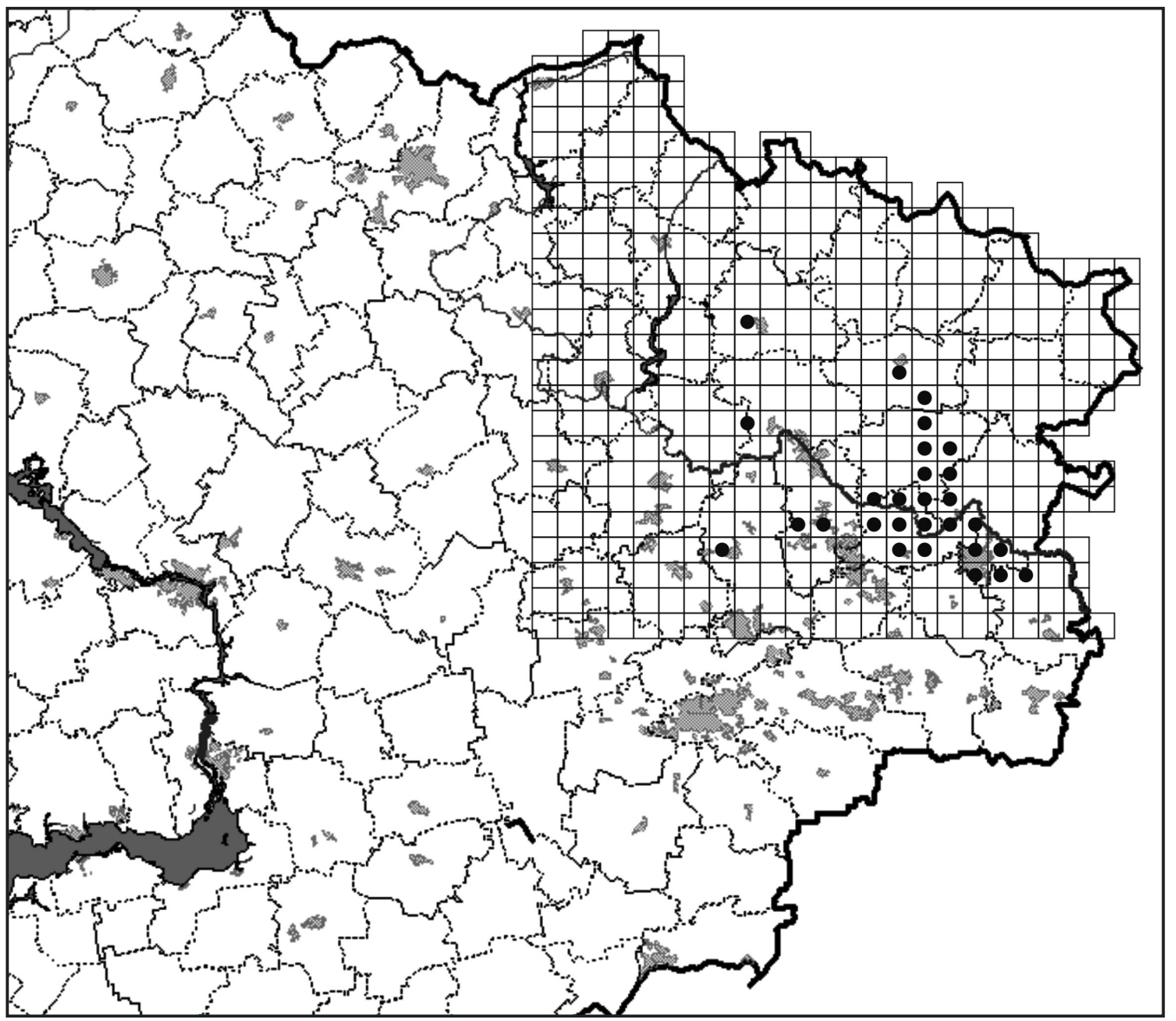

Fig. 4. Distribution map of Grindelia squrrosa (Pursh) Dunal in the Starobilsk grass-meadow steppe 
artemisiifolia tends to invade the affected communities in the steppe areas of Luhansk Nature Reserve and natural meadow flora complexes.

Amaranthus retroflexus (kenophytes epekophyt, ksenophytes, terophyt, xeromesophytes, scyheliophytes; it stands moderate shading - Protopopova \& Shevera 2014). A. retroflexus is the species of North American origin, cosmopolitan and widespread on all continents. In its native area, it grows in the prairie of the Great Plains (USA). A. retroflexus has been introduced into the territory of Ukraine in the late $19^{\text {th }}$ century. The first locality found in the area of Starobilsk grass-meadow steppe is dated at 1907 (Konoplja \& Drel 1998). Then, the plant was spread in the region by railway. It is cultivated as fodder.

A. retroflexus often occurs on disturbed soils along roads, where it can form almost monodominant communities and also along railway tracks. It is often found in the floodplain of Seversky Donets River, on moist and rich soils. In the Starobelsk grass-meadow steppe, the species occurs on sandy soils in artificial plantations of Acer negundo and Pinus sylvestris. We found it also on a chalky outcrop, at the foot of the hill in the village of Melovatka in the Svatove district. It prevails in almost all the types of cultivated agricultural biotopes.
A. retroflexus often occurs in gardens, flower beds and lawns, in rich, light soil. We also found $A$. retroflexus in the areas belonging to the natural reserve fund of Ukraine - in the Luhansk Nature Reserve (Provalske and Trohizbenske departments) (Fig. 6).

Amorpha fruticosa L. (kenophytes, epoecophytes, ergasiophytes, phanerophytes, mesophytes, heliophytes - Vinogradova et al. 2009). A. fruticosa is a species of North American origin. It has been cultivated in Ukraine since 1895 (Protopopova et al. 2009; Protopopova \& Shevera 2014). In the study area, the species was first planted in 1894 in the Derkul forestry district (Burda 1991).

In the Starobelsk grass-meadow steppe, A. fruticosa inhabits mainly artificial pine stands on sandy soils. In the middle of last century, $A$. fruticosa was actively planted in silvicultural plantations for afforestation of sands. The protecting forests with $A$. fruticosa were planted even in the nature reserve buffer zone, along the Streltsivska and Stanychno-Luhansk departments (Fig. 7). The species spread quickly and replaced natural undergrowth. Now, A. fruticosa actively spreads in the floodplain of Seversky Donets River and its tributaries. It also often grows along roads in the affected areas.

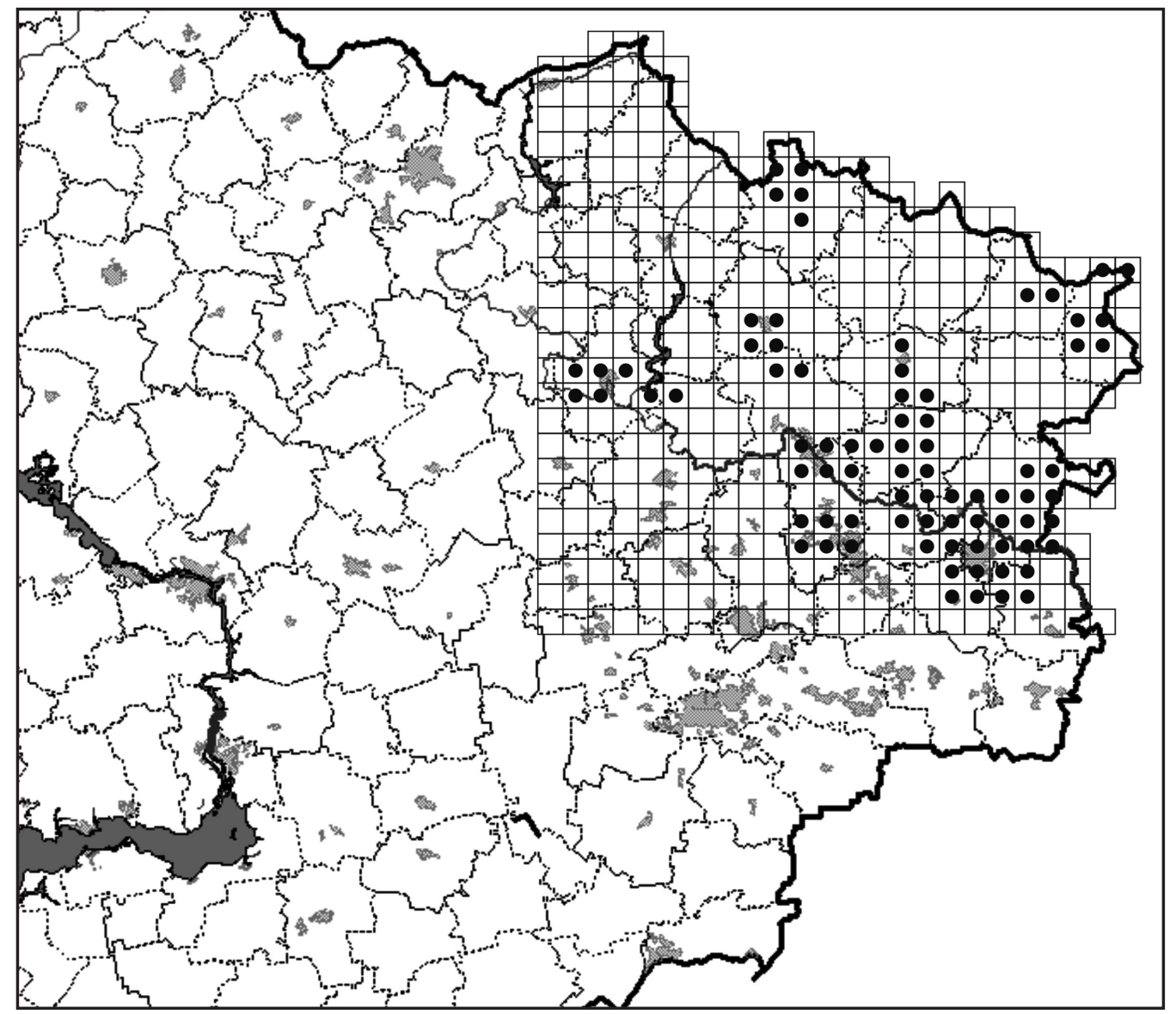

Fig. 5. Distribution map of Ambrosia artemisiifolia L. in the Starobilsk grass-meadow steppe 


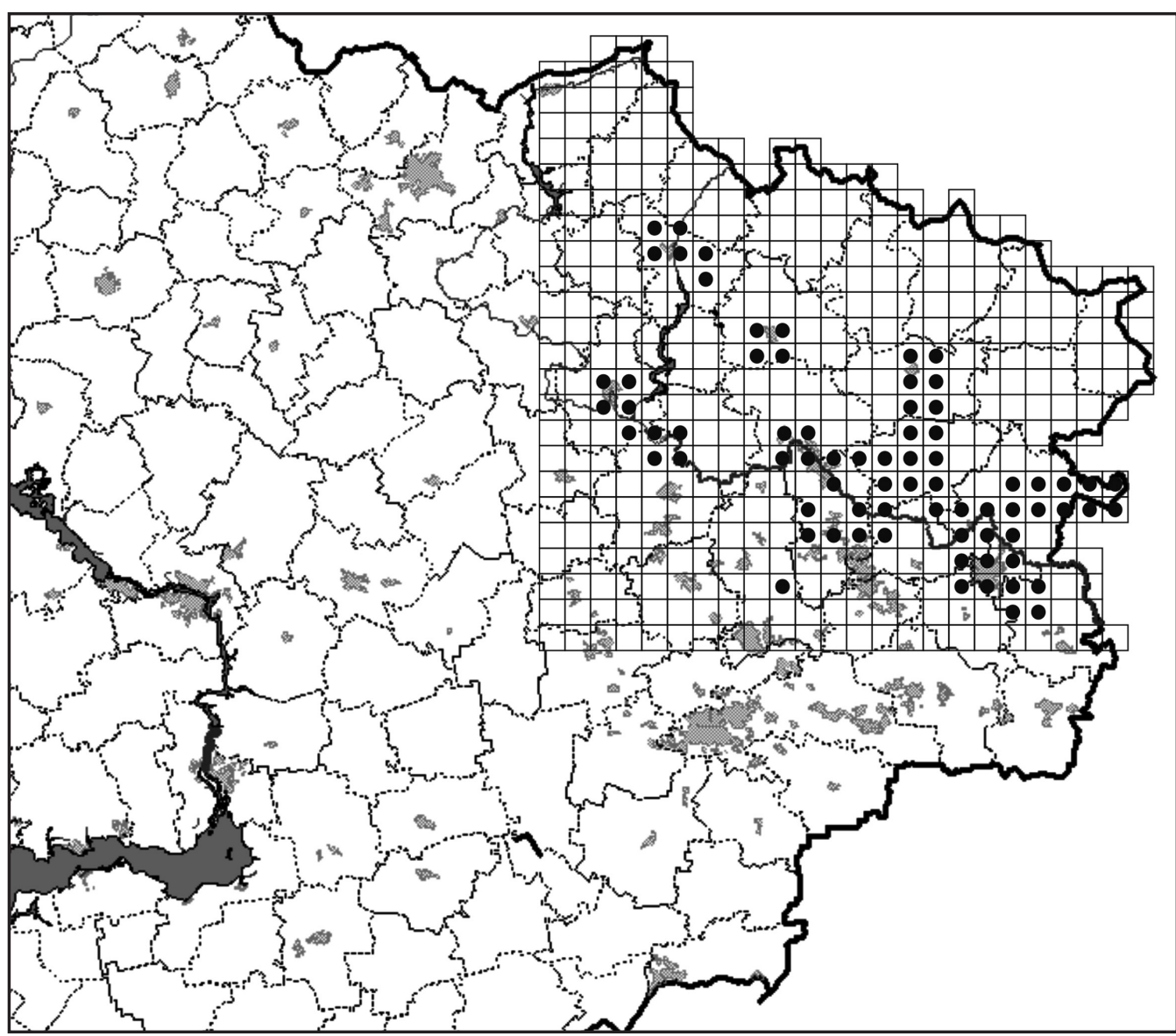

Fig. 6. Distribution map of Amaranthus retroflexus L. in the Starobilsk grass-meadow steppe

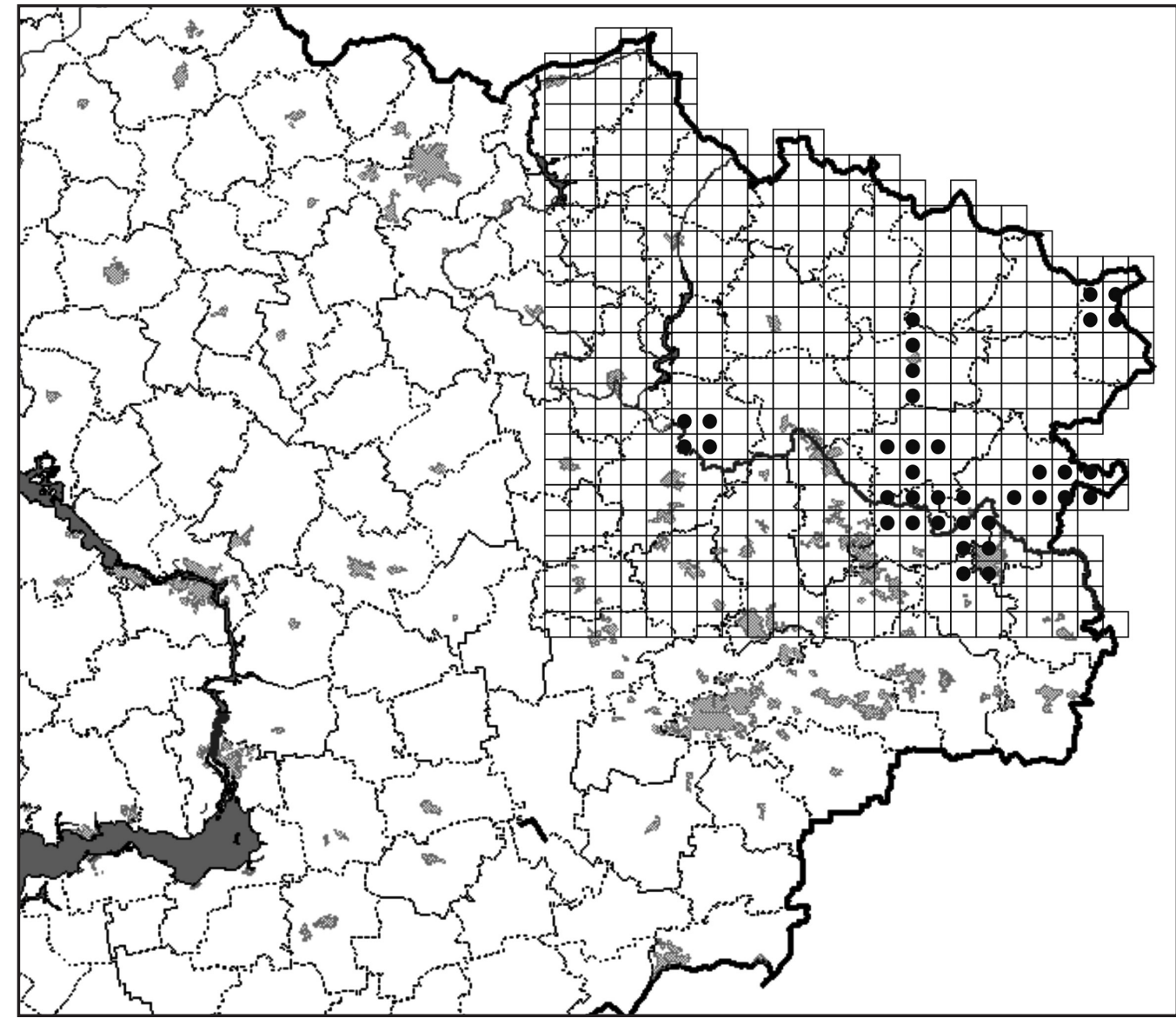

Fig. 7. Distribution map of Amorpha fruticosa L. in the Starobilsk grass-meadow steppe 


\section{Conclusion}

All transformer species in the flora of Starobilsk grass-meadow steppe are kenophytes, most of them, except of Ulmus pumila (Central Asian), are of the North American origin. All the species were brought into the territory of Ukraine in the late nineteenth early twentieth century. Species began to spread in the area of Starobilsk grass-meadow steppe in the second half of the 20th century. Half of transformer species are phanerophytes (trees), one species is hemikryptophyte, two are terophytes. In terms of the way of introduction, no dominant group was identified among transformer species in the investigated territory; three species are ergasiophytes and three xenophytes.

Almost all studied species were cultivated by humans in a certain period of their spread. The only exception is Grindelia squarrosa. It should be noted that tree species, at least 50 years old, were cultivated in botanical gardens before started their expansion associated with active use in landscaping and reclamation. Instead, herbaceous plants did not require a long period for naturalization and spread across almost immedia- tely. A striking example of this is the rapid spread of Amaranthus retroflexus. During expansion, the studied species actively spread in the area, occupying vacant lots not only in ruderal ecotypes, but also in semi natural vegetation. Most transformer species in the Starobilsk grass meadow steppe are epekophytes, according to the degree of naturalization. The only exception is Acer negundo, which is an agriophyte.

In terms of environmental factors, we analyzed the species according to their water and light requirements. The vast majority of them are heliophytes. Only two species, Acer negundo and Amaranthus retroflexus, are scyo-heliophytes. Four transformer species are xeromesophytes, and two, Amorpha fruticosa and Ulmus pumila - mesophytes. Most plants can withstand dry conditions and light exposure. This enables them to root quickly in the disturbed habitats of Ukrainian steppe zone and even interfere with semi natural vegetation.

Acknowledgements. We would like to thank Dr. Myroslav Shevera (M. G. Kholodny Institute of Botany, NAS of Ukraine) for comments on the article and Dr Olena M. Peregrym (M. G. Kholodny Institute of Botany, NAS of Ukraine) for reading the English text.

\section{References}

Budzhak V. V., Chorney I. I. \& Tokaryuk A. I. 2009. To the method of mapping floras species (on the example of Chernivtsi region). Scientific Journal (Biology) Chernivtsy 445: 168-170.

BURDA R. I. 1991. Anthropogenic transformation of the Flora. 168 pp. Naukova Dumka, Kiev.

Burda R. I. 1997. The checklist of Donbass's urban flora. 50 pp. Donetsk.

Chernyaev V. M. 1859. Konspekt rasteniĭ dikorastushchikh i razvodimykh v okrestnostyakh Kharkova i v Ukraĭne. 90 pp. Kharkov.

DidukH Ya. P. (ed.). 2000. Ecoflora of Ukraine. Vol. 1, 284 pp. Phytosociocentre, Kiev.

Fedorov A. A. (ed.). 1974-1987. Flora Partis Europeae URSS, vol. 1-6. Nauka Press, Leningrad.

Hrossheym A. A. \& Akynfyev I. J. 1907. Dikaya rastitel 'nost' Slavyanocerbskogo uezda. Proceedings of the Society of Naturalists Kharkiv University 41(2): 138-151.

Kharhota G. I. 1976. New location Grindelia squarrosa (Pursh) Dunal in Donbass. Ukr. Bot. J. 33(5): 545546.

Kondratyuk E. N., Burda R. I. \& Ostapko V. M. 1985. Check-list of flora of the South-East of Ukraine. 271 pp. Naukova Dumka Press, Kiev.

Konoplja N. I. \& Drel V. F. 1998. Alien flora railways of Lugansk region. 161 pp. Alma-Mater Press, Lugansk.

KoRNAŚ J. 1968. Geograficzno-historyczna klasyfikacja roślin synantropijnych. Mater. Zakł. Fitosoc. Stos. U.W. 25: 33-41.
Kotov M. I. 1949. Adventive vegetation of USSR. Ukr. Bot. J. 6(1): 74-78.

Kucher O. O. 2011. The history of the study of adventive plants of Starobilsk steppe of south-east of Ukraine. Industrial Botany. Donetsk Botanical Garden of NAS of Ukraine, Donetsk 11: 141-146.

Kucher O. O. 2012. Invasive species Grindelia squrrosa (Pursh) Dunal. in the east of Ukraine. In: I. ZAGORODNIUK (ed.). Dynamics of biodiversity, p. 96-99. Taras Shevchenko Lugansk National Universitat, Luhansk.

Kucher O. O. \& Guz’ G. V. 2014. The methodology of Starobilsk grass-meadow steppe flora mapping. The journal of V. N. Karazin. Kharkiv National University, series "Biology". 1100(20): 335-338.

Marynych O. M., Parkhomenko G. A., Petrenko A. M. \& Shischenko P. G. 2003. The improved scheme of physiographic zoning of Ukraine. Ukr. Geogr. Journ. 1: 16-21.

Mosyakin S. L. \& FedoronchuK N. M. 1999. Vascular plants of Ukraine. A nomenclatural checklist. xxiii+345 pp. M. G. Kholodny Institute of Botany, NAS of Ukraine, Kiev.

Ostapko V. M., Boyko A. V. \& Mosyakin S. L. 2010. Vascular plants of South-Eastern of Ukraine. 247 pp. Noulidzh Press, Donetsk.

Protopopova V. V 1973. Alien plants of Forest-Steppe and Steppe of Ukraine. 192 pp. Naukova dumka Press, Kiev. 
Protopopova V. V. 1991. Synantropic flora of Ukraine and its Development. 204 pp. Naukova Dumka Press, Kiev.

Protopopova V. V., Mosyakin S. L. \& Shevera M. V. 2002. Plant invasions in Ukraine as a threat to biodiversity: the present situation and tasks for the future. $32 \mathrm{pp}$. M. G. Kholodny Institute of Botany, NAS of Ukraine, Kiev.

Protopopova V. V. \& Shevera M. V. 2014. Ergasiophytes of the Ukrainian flora. Biodiv. Res. Conserv. 35: 31-46.

Protopopova V. V., Shevera M. V., Bagrikova N. A. \& Riff L. E. 2012. Transformer species in the flora of the South Coast of Crimea. Ukr. Bot. J. 69(1): 54-68.

Protopopova V. V., Shevera M. V., Chorney I. I., Tokaryuk A. V., Budzhak V. V. \& Korzhan K. V. 2010. The transformers species in the flora of Bucovina CisCarpathian area. Ukr. Bot. J. 67(6): 852-863.

Protopopova V. V., Shevera M. V., Mosyakin S. L., Solomakha V. A., Solomakha T. D., Vasilyeva T. V. \& Petryk S. P. 2009. The transformer species in the flora of the Northern Black Sea. Ukr. Bot. J. 66(6): 770-782.

Protopopova V. V., Shevera M. V., Mosyakin S. L., Solomakha V. A., Solomakha T. D., Vasilyeva T. V. \& Petryk S. P. 2009. Invasive plants in the flora of the Northern Black Sea Region (Ukraine). 60 pp. Phytosociocentre, Kiev.

Raunkiaer C. 1934. The life form of plants and statistical plant geography. 632 pp. Claredon, Oxford.
Richardson D. M., Pyšek P., Rejmanek M., Barbour M. G., Panetta F. D. \& West C. J. 2000. Naturalization and invasion of alien plants: concepts and definitions. Diversity Distrib. 6: 93-107.

Schmalhausen I. F. 1895. Flora Sredneĭ i Yuzhnoĭ Rossii, Kryma iSeverphogo Kavkaza. 742 pp. Kiev.

TALIYEV V. I. 1907. For information about the vegetation Starobelsky district in the Kharkiv province. News of Sankt-Petersburg Botanical Garden 3: 101-112.

TokHtar V. K. 2005. New finds synanthropic species in the South-Eastern Ukraine. Indastial Botany. Donetsk Botanical Garden of NAS of Ukraine, Donetsk 5: 61-66.

Tzvelev N. N. (ed.). 1989-1994. Flora Partis Europeae URSS, vol. 7-8. Nauka Press, Leningrad.

Tzvelev N. N. (ed.). 1996-2004. Flora Europae Orientalis, vol. 9-11. Mir I Sem'ya Press, Moscow-Sankt Petersburg.

Uhrynsky K. A. \& Shiryaev G. I. 1903. Materials for the flora of South parts Starobelsky and Eastern part of Kupyansk district of the Kharkiv province. Proceedings of Kharkov Society Naturalists' 38(1): 145-234.

Vasiliev N. G. 1986. Ilm. 88 pp. Agropromizdat Press, Moscow.

Vinogradova Y. K., Mayorov S. R. \& Khorun L. V. 2009. Black book of flora of the Middle of Russia. 494 pp. Geos, Moscow. 